\title{
Dietary Fat Intake and its Association with Adiposity and Inflammatory Markers in Individuals at Cardiometabolic Risk
}

Fernanda Santos Fortes, ${ }^{(0)}$ Alinne Paula de Almeida, ${ }^{(i)}$ Carla de Oliveira Barbosa Rosa, ${ }^{(\bullet)}$ Brenda Kelly Souza Silveira, ${ }^{\circledR}$ Nínive de Almeida Reis, ${ }^{\circledR}$ Helen Hermana Miranda Hermsdorff ${ }^{\circledR}$

Universidade Federal de Viçosa, Viçosa, MG - Brazil

\section{Abstract}

Background: Fatty acids are important components of diet that may influence the development of CVD.

Objective: To verify the relationship of dietary fatty acids with cardiometabolic markers in individuals at the cardiometabolic risk.

Methods: This cross-sectional study involved 282 subjects ( $116 \mathrm{M} / 166 \mathrm{~F}, 42 \pm 16$ years) attended the Cardiovascular Health Care Program, Universidade Federal de Viçosa (Brazil). Anthropometric and body composition measurements as well as metabolic and inflammatory markers were assessed by standard procedures. Demographic and lifestyle variables were obtained by semi-structured questionnaire. Food consumption was evaluated by $24 \mathrm{~h}$ recall. Student's t-test or Mann-Whitney-U test and chi-square test were used, considering the statistical significance level of $5 \%$ probability.

Results: Individuals who eaten fat, fatty acids saturated and fatty acids polyunsaturated above recommendation (>35, 7\%, and $10 \%$ of caloric intake) were more likely to be overweight $(p<0.05)$. Those individuals with higher intake of medium-chain fatty saturated acids $(\geq 1.05 \mathrm{~g} / \mathrm{d})$ had lower values $(\mathrm{p}<0.05)$ of body mass index, waist circumference, waist-hip ratio and waist-height ratio and higher values $(p<0.05)$ of total leukocytes, C-reactive protein and total cholesterol, and LDL. Subjects with higher of palmitoleic acid intake $(\geq 0.94 \mathrm{~g} / \mathrm{d})$ presented higher values of BMI, fat percentage and HOMA-IR $(\mathrm{p}<0.05)$.

Conclusion: This cross-sectional study found different associations of dietary fat and cardiometabolic risk related to adiposity and inflammatory markers, according with chain-size and saturation, indicating the need the more detailed on the dietary assessment of obese patients to identify risk factors and established best strategies to control. (Int J Cardiovasc Sci. 2020; 33(5):447-456)

Keywords: Cardiovascular Diseases, Risk Factors; Metabolic, Syndrome; Obesity/prevention and control; Fatty, Acids; Biomarkers.

\section{Introduction}

The prevalence of overweight and obesity has grown at an alarming rate $^{1}$, and sedentary lifestyle and inadequate dietary patterns, with high fat and sugar intake contribute to the positive energy balance. ${ }^{1,2}$ In addition, excessive fat accumulation, mainly in the abdominal region, has been implicated in the development of other chronic noncommunicable diseases (CNCD), such as diabetes

Mailing Address: Helen Hermana Miranda Hermsdorff

Department of Nutrition and Health, UFV campus. Postal Code: 36570-900,

Viçosa, Minas Gerais - Brazil.

E-mail: helenhermana@ufv.br
(DM), dyslipidemias, systemic arterial hypertension and cardiovascular diseases (CVD). ${ }^{3}$

In this context, fatty acids are important components of diet that may influence the development of CVD, since fatty acids participate in important biological functions, such as energy substrate, regulation of metabolic pathways and inflammatory processes,

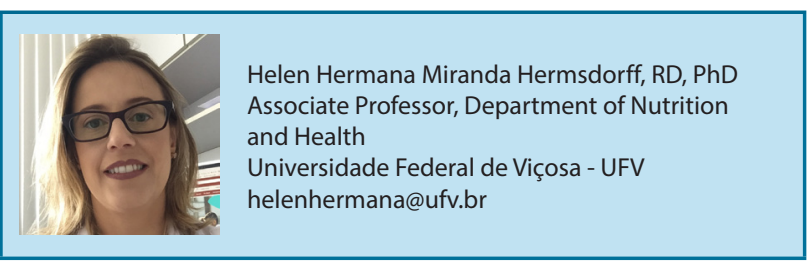

Manuscript received April 03, 2019; revised manuscript 0ctober 16, 2019; accepted November 24, 2019. 
hormone production, and participate in complex systems of intracellular signaling. Derivatives of fatty acids also act on the synthesis of prostaglandins, leukotrienes and thromboxanes,,${ }^{4,5}$ being dietary fat important modulator of inflammatory status and cardiovascular risk. ${ }^{6}$

The medium chain fatty acids are absorbed in the non-esterified form and transported to the liver, bound to albumin, where they are rapidly metabolized. In turn, long-chain fatty acids undergo a process of esterification, forming triglycerides, which can remain in the bloodstream, carried by chylomicrons, or released into the tissues, acting as a form of fat storage in the body. Thus, excessive deposition of these lipids may lead to an increase in CVD. ${ }^{7}$ However, little is known about the relationship between the consumption of medium and long chain fatty acids and cardiovascular risk parameters.

Dietary fatty acids can also be classified as saturated (SFA), monounsaturated (MUFA), and polyunsaturated (PUFA), according to saturation level. In this sense, high MUFA diet causes reduction in serum levels of total cholesterol, low density lipoprotein (LDL-c), triglycerides and increase in high density lipoprotein (HDL-c) ${ }^{8,9}$ The PUFAs, especially those of the omega 3 series, are recognized by cardioprotective activity. However, SFAs are associated with proven deleterious effects, since they increase triglyceridemia and cholesterolemia, and have a proinflammatory action..$^{10}$ Regarding inflammation modulation by fat, Studies have found strong association of saturated fat intake with the synthesis of inflammatory biomarkers compared to polyunsaturated fatty acids. ${ }^{11,12}$

In this sense, the objective of the present study was to verify the relationship between dietary fatty acids and cardiometabolic markers in individuals at cardiometabolic risk treated at the Cardiovascular Assistance Program of the Federal University of Viçosa (PROCARDIO-UFV).

\section{Methodology}

\section{Subjects}

Participated in this cross-sectional study 282 patients included in PROCARDIO-UFV and had their first consultation until July/2016. PROCARDIO-UFV is a program that performs nutritional intervention to promote cardiovascular health in the academic community of UFV, registered in the Brazilian Clinical Trials Registry (ReBEC, number RBR-5n4y2g7). ${ }^{13}$ The inclusion criteria in the program are: men and women; patients $\geq 20$ years of age; students, workers and workers' dependents UFV; cardiovascular disease or occurrence of at least one cardiometabolic risk factor: overweight or obesity (Body Mass Index $(\mathrm{BMI}) \geq 25$ or $\left.27 \mathrm{Kg} / \mathrm{m}^{2}\right)^{14,15}$ or/and dyslipidemia (Triglycerides (TG) $\geq 150 \mathrm{mg} / \mathrm{dL}$ or/and Total cholesterol (TC) $\geq 200 \mathrm{mg} / \mathrm{dL}$ or/and HDL-c $<40$ or $<50 \mathrm{mg} / \mathrm{dL}$ for men and women $)^{10,16}$ or/and blood pressure $\geq 130 / \geq 85 \mathrm{mmHg}^{16}$ or diagnosed hypertension or/and fasting glucose $\geq 110 \mathrm{mg} /$ $\mathrm{dL}^{16}$ or diagnosed diabetes mellitus.

The study did not include individuals who were not associated with the UFV, who did not present cardiometabolic risk or CVD, pregnant women, children and adolescents.

The study was approved by the Human Research Ethics Committees of the UFV ( $n^{\circ}$ 066/2012/CEPH), in accordance to the Resolution 466/2012 of the National Health Council (CNS/Ministry of Health, Brazil) and to principles of the Declaration of Helsinki. All participants of the study read and signed the written informed consent form.

The data used were related to the first consultation. Of the 417 program users, 282 were selected for having complete data fatty acid intake.

\section{Dietary Assessment}

The volunteers responded to a 24-hour recall, reporting all food and drink consumed the day before (weekend or weekday) the consultation, as well as their quantities. In the present study, the daily intake of calories and total lipids (SFA, MUFA, and PUFA) were assessed using software, DietPRO, version 5.0i.

The determination of the intake of caprylic (C8: 0), capric (C10: 0), lauric (C12: 0), myristic (C14: 0), palmitic (C16: 0), stearic (C18: 1), SFA and oleic MUFA (C18: 1), linoleic (C18: 2, LA, family $\omega-6)$ and $\alpha$-linolenic PUFA (C18: 3, LNA, family $\omega-3$ ) and trans fatty acids were performed using the National Nutrient Database for Standard Reference (USDA) table. ${ }^{17}$ The foods present in the recall and not listed in the USDA table had their composition estimated considering foods that presented nutritional composition and similar cooking methods. ${ }^{17}$ In addition, the preparations were dismembered in their constituent ingredients and, in the case of not having the option of the composition for the cooked food, the raw food composition was used. The intake of each fatty acid was performed using a standard spreadsheet (Microsoft Excel $^{\circledR}$ ), developed specially for this aim.

Medium chain fatty acids were the sum of C8: 0 (caprylic acid), C10: 0 (capric acid) and C12: 0 (lauric acid). 
And as long chain fatty acids the sum of myristic (C14: 0), palmitic (C16: 0) and stearic (C18: 0), monounsaturated fatty acids palmiticleic (C16: 1) and oleic (C18: 1) fatty acids (C18: 2, LA, family $\omega-6)$ and $\alpha$-linolenic acid (C18: 3, LNA, $\omega$-3 family). Adequate consumption of total fat, SFA, MUFA, PUFA and linoleic fatty acid was considered when the ingestion was between 25 and $35 \% ; \leq 7 \%$; $\leq 20 \%$; $\leq 10 \%$ of the daily energy value and between 1.1 and 1.6 g/day, respectively. ${ }^{10}$ To assess the possible association of palmitoleic acid consumption and other variables of interest, the present study sample was categorized according to the median palmitoleic acid consumption (0.94g/day), medium chain fatty acids consumption (1.05 g/day) and long-chain fatty acids (LCFA) (18.92 g/day). The use of the median as a cutoff point has been used ${ }^{18,19}$ based on the premise of the creation of risk groups in epidemiological studies. ${ }^{20}$

\section{Anthropometry and Body Composition}

Body weight and height were measured using a standardized protocol ${ }^{21}$

The Waist circumference was measured on the umbilical scar and hip ratio and waist-to height ratio were calculated. Waist circumference (WC) was measured from the umbilical scar in the horizontal plane. ${ }^{22}$

Abdominal obesity was considered WC greather than or equal to 80 and $90 \mathrm{~cm}$ for women and men respectively. ${ }^{23}$ Waist-to-height ratio $(\mathrm{WH}+\mathrm{R})$ and waistto-hip ratio (WHR) were also calculated. $\mathrm{WH}+\mathrm{R}$ and classified as high risk for (CVD) when $\geq 0,5$ (both sexes); 0,85 (women) and 1.00 (men), respectively. ${ }^{24,25}$ Total body fat $(\mathrm{BF} \%)$ was assessed by tetrapolar electrical bioimpedance analysis, performed with standard protocol. ${ }^{26}$ Obesity was diagnosed according to cut-off points proposed by Bray et al..$^{27}$ : > 33 and $25 \%$ for women and men, respectively.

\section{Metabolic Biomarkers}

Fasting serum glucose, triglycerides, total cholesterol HDL, ferritin, uric acid and ultra-sensitive C-reactive protein (CRP-us) total leukocytes, were determined at the Laboratory of Clinical Analysis of the Health Division of the UFV, according to standardized protocol of this Laboratory.

Insulin resistance was estimated by the homeostasisinsulin resistance (HOMA-IR) model, which was calculated as follows: HOMA-IR $=$ [fasting glucose $(\mathrm{mmol} / \mathrm{L})]$ fasting insulin $(\mu \mathrm{UI} / \mathrm{ml})] / 22.5$ and by the index triglycerides/glycemia (TyG), which was calculated as follows: Ln [fasted triglycerides $(\mathrm{mg} / \mathrm{dl}) \times$ fasting blood glucose $(\mathrm{mg} / \mathrm{dl}) / 2]{ }^{28}$

\section{Demographic and Lifestyle Variables}

The variables age, sex, schooling, income, smoking, regular practice of physical activity and alcohol consumption were collected through interview of the participants.

\section{Statistical Analyzes}

The results were presented in absolute and relative frequencies, mean \pm standard deviation and, or median (p25-p75). The normality of each variable was assessed by the Kolmogorov-Smirnov test. All dietary intake variables were adjusted by total caloric intake using the residual method, as proposed by WILLETT \& STAMPFER. ${ }^{29}$

Non-paired Student-t and Mann-Whitney-U tests were used for comparison of two groups, where appropriate. Pearson's chi-square test was used to verify associations between socio-demographic variables, lipid consumption and nutritional status. All statistical analyzes were performed using the SSPS $21.0^{\circledR}$ program. We considered the level of statistical significance of $5 \%$ probability.

\section{Results}

Of the 282 subjects, $58.9 \%$ were female; $81.9 \%$ adults; $53.4 \%$ individuals reported practicing physical activity (self report) and $17.4 \%$ had diabetes. Of the overweight individuals, $76.6 \%$ were dyslipidemic $(p=0.028)($ Table 1$)$.

Table 2 shows dietary fat intake according to weightstatus. Among the overweight individuals, 45.7\% presented fat intake within the recommendation, but $79.7 \%$ of individuals consumed above recommendation to SFA.

The individuals (normal-weight and overweight) with higher consumption of medium chain fatty acids had lower values $(\mathrm{p}<0.05)$ for BMI, perimeters of the waist, hip waist ratios, waist height ratios, ferritin, glycemia and uric acid. On the other hand, they had higher values $(\mathrm{p}<0.05)$ of total leukocytes, total cholesterol, low density lipoprotein (LDL), HDL and CRP (Table 3). However, for long-chain fatty acids, only the total leukocyte count was significant $(p=0.038)$ for those with higher consumption ( $\geq 18.92 \mathrm{~g} /$ day) (data not shown). Individuals with higher intakes of palmitoleic 
Table 1 - Characteristics PROCARDIO-UFV participants, according to body fat-status

\begin{tabular}{|c|c|c|c|c|}
\hline Variables n (\%) & Total $(n=282)$ & Normal-weight $(\mathrm{n}=85)$ & Overweight $(\mathrm{n}=197)$ & p-values \\
\hline \multicolumn{5}{|l|}{ Sex } \\
\hline Male & $116(41.1)$ & $33(38.8)$ & $83(42.1)$ & \multirow[b]{2}{*}{0.604} \\
\hline Female & $166(58.9)$ & $52(61.2)$ & $114(57.9)$ & \\
\hline \multicolumn{5}{|l|}{ Age } \\
\hline Adults & $231(81.9)$ & $64(75.3)$ & $167(84.8)$ & \multirow{2}{*}{0.058} \\
\hline Seniors & $51(18.1)$ & $21(24.7)$ & $30(15.2)$ & \\
\hline \multicolumn{5}{|l|}{ Schooling $(n=265)$} \\
\hline Illiterate incomplete/high school & $62(23.4)$ & $17(21.5)$ & $45(24.2)$ & \multirow{3}{*}{0.479} \\
\hline Complete high school & $46(17.4)$ & $11(13.9)$ & $35(18.8)$ & \\
\hline Graduated/incomplete graduated & $157(59.2)$ & $51(64.6)$ & $106(57.0)$ & \\
\hline \multicolumn{5}{|l|}{ Income } \\
\hline Did not inform & $30(10.6)$ & $12(14.1)$ & $18(9.1)$ & \multirow{5}{*}{0.399} \\
\hline Up to 2 wages & $66(23.4)$ & $19(22.4)$ & $47(23.9)$ & \\
\hline 2 to 4 salaries & $103(36.5)$ & $25(29.4)$ & 78 (39.6) & \\
\hline 4 to 10 salaries & $71(25.2)$ & $25(29.4)$ & $46(23.4)$ & \\
\hline More than 10 wages & $12(4.3)$ & $4(4.7)$ & $8(4.1)$ & \\
\hline \multicolumn{5}{|l|}{ Smoking $(\mathrm{n}=281)$} \\
\hline Never smoked & $189(67.3)$ & $65(77.4)$ & $124(62.9)$ & \multirow{3}{*}{0.014} \\
\hline Have you smoked & $80(28.5)$ & $14(16.7)$ & $66(33.5)$ & \\
\hline Smokes currently & $12(4.2)$ & $5(6)$ & $7(3.6)$ & \\
\hline \multicolumn{5}{|l|}{ Physical activity $(\mathrm{n}=281)$} \\
\hline No & $131(46.6)$ & $42(49.4)$ & $89(45.4)$ & \multirow{2}{*}{0.537} \\
\hline Yes & $150(53.4)$ & $43(50.6)$ & $107(54.6)$ & \\
\hline \multicolumn{5}{|l|}{ Alcohol drink $(n=277)$} \\
\hline Never drinks & $114(41.2)$ & $34(41)$ & $80(41.2)$ & \multirow{3}{*}{0.648} \\
\hline Eventually & $156(56.3)$ & $48(57.8)$ & $108(55.7)$ & \\
\hline Daily & $7(2.5)$ & $1(1.2)$ & $6(3.1)$ & \\
\hline \multicolumn{5}{|l|}{ Hypertension $(n=281)$} \\
\hline No & $173(61.6)$ & $67(79.8)$ & $106(53.8)$ & \multirow{2}{*}{$<0.001$} \\
\hline Yes & $108(38.4)$ & $17(20.2)$ & $91(46.2)$ & \\
\hline \multicolumn{5}{|l|}{ Diabetes $(n=281)$} \\
\hline No & $232(82.6)$ & $67(79.8)$ & $165(83.8)$ & \multirow{2}{*}{0.419} \\
\hline Yes & 49 (17.4) & $17(20.2)$ & $32(16.2)$ & \\
\hline \multicolumn{5}{|l|}{ Dyslipidemia $(n=281)$} \\
\hline No & $56(19.9)$ & $10(11.9)$ & $46(23.4)$ & \multirow{2}{*}{0.028} \\
\hline Yes & $225(80.1)$ & $74(88.1)$ & $151(76.6)$ & \\
\hline
\end{tabular}

Variables expressed as absolute and relative frequency. P values in bold refer to statistical significance $(p<0.05)$ using the Pearson chi-square test. *Variables self-reported by participants. 


\begin{tabular}{|c|c|c|c|}
\hline Fat intake & $\begin{array}{l}\text { Normal- } \\
\text { weight } \\
(\mathrm{n}=85)\end{array}$ & $\begin{array}{l}\text { Overweight } \\
(\mathrm{n}=197)\end{array}$ & p-values \\
\hline \multicolumn{4}{|l|}{ Total fat } \\
\hline$<25 \% \mathrm{CI}(\mathrm{n}=93)$ & $37(43.5)$ & $57(28.9)$ & \multirow{3}{*}{0.011} \\
\hline $\begin{array}{l}25 \%-35 \% \mathrm{CI} \\
(\mathrm{n}=127)\end{array}$ & $38(44.7)$ & $90(45.7)$ & \\
\hline$>35 \% \mathrm{CI}(\mathrm{n}=60)$ & $10(11.8)$ & $50(25.4)$ & \\
\hline \multicolumn{4}{|l|}{ Saturated fatty acid } \\
\hline$\leq 7 \% \mathrm{CI}(\mathrm{n}=68)$ & $29(34.1)$ & $40(20.3)$ & \multirow{2}{*}{0.013} \\
\hline$>7 \% \mathrm{CI}(\mathrm{n}=212)$ & $56(65.9)$ & $157(79.7)$ & \\
\hline \multicolumn{4}{|l|}{$\begin{array}{l}\text { Polyunsaturated } \\
\text { fatty acid }\end{array}$} \\
\hline$\leq 10 \% \mathrm{CI}(\mathrm{n}=252)$ & $82(96.5)$ & $172(87.3)$ & \multirow{2}{*}{0.018} \\
\hline$>10 \% \mathrm{CI}(\mathrm{n}=28)$ & $3(3.5)$ & $25(12.7)$ & \\
\hline \multicolumn{4}{|l|}{$\begin{array}{l}\text { Monounsaturated } \\
\text { fatty acid }\end{array}$} \\
\hline$\leq 20 \% \mathrm{CI}(\mathrm{n}=275)$ & $84(98.8)$ & $193(98.0)$ & \multirow{2}{*}{0.618} \\
\hline$>20 \% \mathrm{CI}(\mathrm{n}=5)$ & $1(1.2)$ & $4(2.0)$ & \\
\hline $\begin{array}{l}\text { Variables expressed as ab } \\
\text { refer to statistical signif } \\
\text { test. CI: caloric intake. }\end{array}$ & $\begin{array}{l}\text { ite and rel } \\
\text { ce }(p<0.0 \text {. }\end{array}$ & $\begin{array}{l}\text { frequency. } p r \\
\text { ing the Pearso }\end{array}$ & $\begin{array}{l}\text { es in bold } \\
\text { hi-square }\end{array}$ \\
\hline
\end{tabular}

acid presented higher values for BMI, body fat (\%) and HOMA-IR (Figure 1).

In relation to PUFA intake, $91.8 \%$ of study participants $(n=259)$ consume less than $0.6 \%$ of the total calories in $\alpha$-linolenic acid, and $60.3 \%(\mathrm{n}=170)$ consume less than $5 \%$ of total calories in linoleic fatty acid. No significant relation was found between the recommended intake of $\alpha$-linolenic acid (0.6-1.2\% of total calories) and linoleic acid (5-10\% of total calories) and cardiometabolic markers, neither there is significant result regarding the consumption of trans fatty acids (data not show).

\section{Discussion}

In this study, $45.7 \%$ and $87.3 \%$ of the individuals with overweight had consumption within the total fat and PUFA recommendations, respectively, and 79.7\% above the recommendation for saturated fatty acids. This result shows the importance of dietary fat assessment regarding to its quality, since dietary fatty acid is more important determinant of cardiovascular risk than its total amount. ${ }^{30,31}$

In previous study, with adults aged 20 to 59 years and overweight prevalence of $76.79 \%$, SFA intake remained within the established values. However, there was an inadequacy of the PUFA consumption being below the recommended level. ${ }^{32}$ This difference in results can be explained by the fact that the authors used the recommendations of up to $7 \%$ of total calories in SFA and up to $10 \%$ of total calories in PUFA, in the study cited, $10 \%$ of total calories and 6 to $10 \%$, respectively.

In the last decades, there have been medical and nutritional recommendations for the reduction of the consumption of SFA due to the action of these in the increase of the LDL-c in the increase of the risk of cardiovascular disease. ${ }^{33}$ However, different SFA may have different effects on the lipid profile and cardiovascular risk factors. ${ }^{34}$

When compared to carbohydrates, lauric fatty acid (C12: 0 ) is what increases the LDL-c and consequently TC. ${ }^{35}$ This may explain the fact that the individuals in the present study had a higher intake of saturated medium chain fatty acids (SCMA), among them lauric acid, with higher values of TC and LDL. Considering the high prevalence of dyslipidemic in this population $(80.1 \%$, $\mathrm{n}=225$ ), this finding may contribute to the prescription of diets, restricting foods containing higher amounts of these fatty acids, such as whole milk and its derivatives, coconut and their derivatives.

Lower values in the adiposity indexes (BMI, perimeters of the waist, hip waist ratios, waist height ratios) of the participants with the highest consumption of SCMA can be explained by the metabolism of the medium chain triglycerides. These are absorbed, mainly as free fatty acids, directly from the portal vein, thus reaching the liver faster than the long chain fatty acids. In the liver, oxidation is rapid because it does not need to be activated by coenzyme A, making it a good ketogenic substrate. ${ }^{36,37}$ In clinical trials with men and women fed a diet containing medium chain triglycerides, mainly lauric acid, they achieved a reduction in body mass and abdominal fat, since these components are not easily incorporated into adipose tissue triglycerides. ${ }^{38-40}$

Inflammation is a prominent feature of many chronic diseases, high-fat and carbohydrate meals contribute to increased oxidative stress and inflammation. ${ }^{41} \mathrm{~A}$ high- 
Table 3 - Indicators of adiposity and cardiometabolic markers, according to the intake of medium chain fatty acids ( $\mathrm{n}=282$ )

\begin{tabular}{|c|c|c|c|}
\hline Variável & Lower intake $(<1,05 \mathrm{~g} /$ day $)$ & Higher intake ( $\geq 1,05 \mathrm{~g} /$ day) & p \\
\hline BMI $\left(\mathrm{kg} / \mathrm{m}^{2}\right)$ & $29.48(5.1)$ & $28.20(5.7)$ & 0.049 \\
\hline Waist circumference (cm) & 99.51(13.6) & $94.09(14.9)$ & 0.002 \\
\hline Waist-hip ratio & $0.96(0.09)$ & $0.91(0.09)$ & $<0.001$ \\
\hline Waist-height ratio & $0.60(0.09)$ & $0.58(0.10)$ & 0.026 \\
\hline Total body fat (\%) & $30.30(6.7)$ & $31.66(9.1)$ & 0.222 \\
\hline Leukocytes $\left(\mathrm{mil} / \mathrm{mm}^{3}\right)$ & $6,000(5,120-7,035)$ & $6,500(5,425-7,750)$ & 0.035 \\
\hline Ferritin $(\mu \mathrm{g} / \mathrm{L})$ & $113.2(54.9-237.7)$ & $66.95(30.5-153.0)$ & 0.012 \\
\hline Uric acid (mg/dL) & $4.5(3.7-6.0)$ & $3.9(3.1-4.7)$ & 0.002 \\
\hline Glycemia (mg/dL) & $96.0(87.0-108.0)$ & $88.0(80.8-97.0)$ & $<0.001$ \\
\hline HOMA-IR & $2.0(1.2-3.4)$ & $2.2(1.5-3.0)$ & 0.900 \\
\hline TyG & $4.8(0.3)$ & $4.8(0.3)$ & 0.113 \\
\hline Total cholesterol (mg/dL) & $195.2(40.6)$ & $215.6(42.8)$ & $<0.001$ \\
\hline LDL (mg/dL) & $118.4(37.4)$ & $130.8(37.6)$ & 0.010 \\
\hline HDL (mg/dL) & $44.7(12.9)$ & $51.4(15.6)$ & $<0.001$ \\
\hline TC/ HDL & $4.64(1.46)$ & $4.49(1.43)$ & 0.402 \\
\hline LDL/HDL & $2.81(1.18)$ & $2.75(1.07)$ & 0.696 \\
\hline Triglycerides (mg/dL) & $140.0(104.0-226.0)$ & $146.5(92.0$ - 227.8) & 0.597 \\
\hline CRP (mg/dL) & $1.3(0.3-3.2)$ & $2.9(0.8-5.8)$ & 0.008 \\
\hline
\end{tabular}

fat meal has been suggested to increase inflammation, although there is currently no consensus regarding the specific changes in many of the pro-inflammatory markers that are often evaluated after a high-fat diet. ${ }^{42}$

SFA can cause inflammation of adipose tissue by processes involving, among others, the "toll-like receptor" TLR-4, a sensor that binds to bacterial lipopolysaccharide (LPS). ${ }^{43}$ High fat diets, especially those rich in SFA, have been shown to increase LPS uptake in the intestine. ${ }^{44,45}$ Evidence suggests that SFA and LPS share the same inflammatory signaling pathway as TLR4, thus promoting the expression of proinflammatory transcription factors such as nuclear kappa B and cyclooxygenase- $2{ }^{42}$

The subjects with higher intake of medium chain fatty acids had a higher total leukocyte count. It has been demonstrated that CRP-us ${ }^{46}$ and leukocyte count $^{47}$ can independently predict vascular risk in apparently healthy men and women, asymptomatic for cardiovascular risk factors. ${ }^{46}$

A study conducted by Raz et al., ${ }^{48}$ with 54 subjects with a BMI of $25 \pm 0.9 \mathrm{~kg} / \mathrm{m}^{2}$, with a mean age of $41.7 \pm$ 3.1 years, demonstrated a significant increase in CRP-us after a high-acid meal (51 g), it did not work when the meal was high in monounsaturated fatty acids.

Wealso found tha individuals with higher intakes of C16: 1 ( $\geq 0.94 \mathrm{~g} /$ day) had higher values for BMI, fat percentage and HOMA-IR. Studies evaluating the palmitoleic MUFA intake and its relation with cardiometabolic markers have not been reported yet. However, some studies have pointed out that higher proportions of palmitoleic acid in blood or adipose tissue are consistently associated with chronic diseases outcomes, such as obesity, ${ }^{49,50}$ hypertriglyceridemia, ${ }^{51}$ hyperglycemia, ${ }^{52}$ inflammation, ${ }^{53,54}$ metabolic syndrome, ${ }^{55,56}$ diabetes type $2,{ }^{57}$ disease coronary heart disease, ${ }^{57}$ and heart failure ${ }^{58}$ In obese individuals 
A

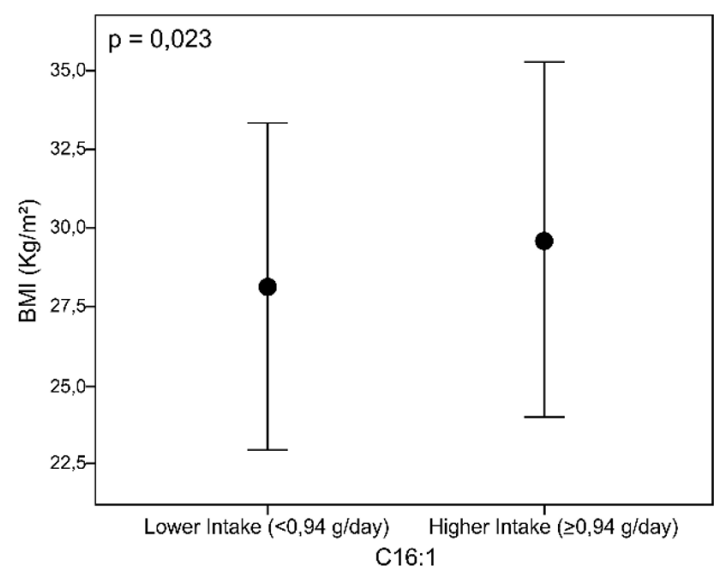

B

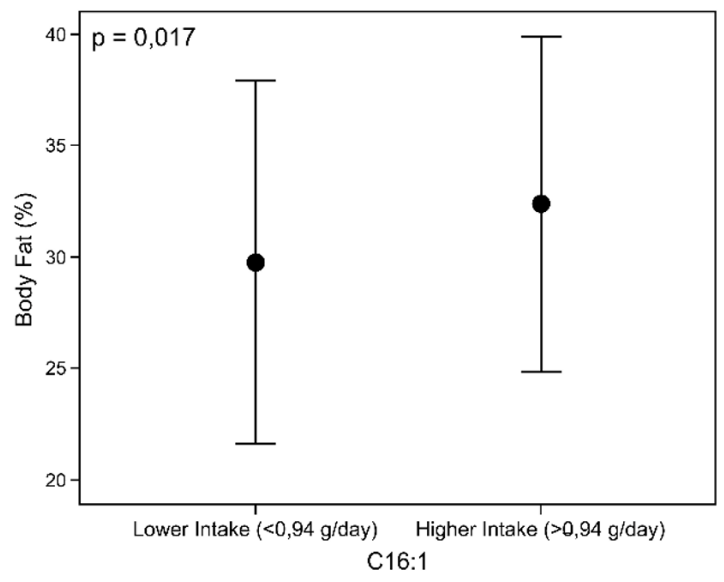

$\mathrm{C}$



Figure 1 - Values of BMI (A), body fat (B) and HOMA-IR (C), according to intake of C16: 1 (palmitoleic acid). Data are mean and standard deviation or median (p25-p75), according to normality. Values of p by t-test or Mann-Whitney, where appropriate. C16: 1 was adjusted by caloric intake by residual method.

with significant weight loss, high palmitoleic acid in adipose tissue was associated with higher inability to maintain weight loss. ${ }^{50}$ Moreover, in 18-week nutrition intervention study, with sixteen metabolic syndrome patients, ${ }^{59}$ plasma palmitoleic acid was gradually increasing when participants fed related low-carbohydrate diet to high-carbohydrate diet (47 to $346 \mathrm{~g} / \mathrm{d}$ ).

The study has as its limitation the use of only a 24-hour recall that provides us with current and not habitual diet information, although this food survey has been extensively used in epidemiological studies to investigate food consumption relationship with chronic diseases. ${ }^{60}$

\section{Conclusion}

In this cross-sectional study, individuals with a higher intake of medium-chain SFA had lower values of indicators of adiposity, ferritin, uric acid, and fasting glucose, and higher leukocyte, CRP, CT, LDL, and HDL concentrations. While higher palmitoleic MUFA consumption was related to higher BMI, fat percentage and HOMA-IR values. Our results suggest the relevance of a detailed assessment of the dietary fatty acid profile in the high-risk cardiometabolic population, considering chain size and saturation. 


\section{Acknowledgments}

We thank PROCARDIO-UFV patients for participating in the study, as well as the professionals by excellent technical assistance.

\section{Author contributions}

Conception and design of the research: Fortes FS, Almeida AP, Silveira BKS, Hermsdorff HHM. Acquisition of data: Fortes FS, Almeida AP, Silveira BKS. Analysis and interpretation of the data: Fortes FS, Almeida AP. Writing of the manuscript: Fortes FS, Almeida AP. Critical revision of the manuscript for intellectual content: Fortes FS, Almeida AP, Rosa COB, Hermsdorff HHM.

\section{Financial Support}

The CAPES Foundation (Ministry of Education, Brazil), CNPq (Ministry of Science, Technology and Innovation, Brazil) and FAPEMIG (Foundation for Research Support of the State of Minas Gerais, Brazil) by $\mathrm{PhD}$ scholarships.

\section{References}

1. Brasil. Ministério da Saúde. Secretaria de Atenção à Saúde. Departamento de Atenção Básica. Estratégias para o cuidado da pessoa com doença crônica obesidade. Cadernos de Atenção Básica, n. 38. Brasília: Ministério da Saúde; 2014.

2. Rombaldi AJ, Silva MC, Neutzling MB, Azevedo MR, Hallal PC. Factors associated with the consumption of high-fat foods among adults in a Southern Brazilian city. Ciênc Saúde Coletiva. 2014;19(5):1513-21.

3. Malta DC, Moura L, Prado RR, Escalante JC, Schmidt MI, Duncan BB. Chronic non-communicable disease mortality in Brazil and its regions, 2000-2011. Epidemiol Serv Saúde. 2014;23(4):599-608.

4. Brito JRS. Perfil de ácidos gordos nos alimentos: validação de um método analítico [dissertação]. Portugal: Universidade de Coimbra; 2014.

5. Lottenberg, AMP. Importance of the dietary fat on the prevention and control of metabolic disturbances and cardiovascular disease. Arq Bras Endocrinol Metab. 2009;53(5):595-607.

6. Nasciutti PR, Costa APC, Júnior MBS, Melo NG, Carvalho ROA. Fatty acid and cardiovascular system. Rev Encicl Biosf. 2015;11(22):11-29.

7. Santos RD, Gagliardi ACM, Xavier HT, Magnoni CD, Cassani R, Lottenberg AMP, et al. I Diretriz sobre o consumo de gorduras e saúde cardiovascular. Arq Bras Cardiol. 2013;100(3):1-40.

8. Gillingham LG, Gustafson JA, Han S-Y, Jassal DS, Jones PJH. Higholeic rapeseed (canola) and flaxseed oils modulate serum lipids and inflammatory biomarkers in hypercholesterolaemic subjects. Br J Nutr. 2011;105(3):417-27.

9. Gilmore LA, Walzem RL, Crouse SF, Smith DR, Adams TH, Vaidyanathan $\mathrm{V}$, et al. Consumption of high-oleic acid ground beef increases HDLcholesterol concentration but both high- and low-oleic acid ground beef

\section{Potential Conflict of Interest}

No potential conflict of interest relevant to this article was reported.

\section{Sources of Funding}

There were no external funding sources for this study.

\section{Study Association}

This article is part of the thesis of master submitted by Nínive de Almeida Reis, from Universidade Federal de Viçosa.

\section{Ethics approval and consent to participate}

This study was approved by the Ethics Committee of the Universidade Federal de Viçosa under the protocol number 066/2012/CEPH. All the procedures in this study were in accordance with the 1975 Helsinki Declaration, updated in 2013. Informed consent was obtained from all participants included in the study.

decrease HDL particle diameter in normocholesterolemic men. J Nutr. 2011;141(6):1188- 94.

10. Faludi AA, Izar MCO, Saraiva JFK, Chacra APM, Bianco HT, Afiune NA, et al. Atualização da Diretriz Brasileira de Dislipidemias e Prevenção da Aterosclerose - 2017. Arq Bras Cardiol. 2017;109(2 Suppl 1):1-76.

11. Harris C, Demmelmair H, Von Berg A, Lehmann I, Flexeder C, Koletzko $B$, et al. Associations between fatty acids and low-grade inflammation in children from the LISAplus birth cohort study. Eur J Clin Nutr. 2017;71(11):1303-11

12. Dias CB, Amigó N, Wood LG, Mallol R, Correig X, Garg ML. Improvement of the omega 3 index of healthy subjects does not alter the effects of dietary saturated fats or n-6PUFA on LDL profiles. Metabolism. 2017 Mar;68:11-19.

13. Registro Brasileiro de Ensaios Clínicos [Internet]. Aplicação de diferentes estratégias de terapia nutricional no Programa de Atenção à Saúde Cardiovascular - PROCARDIO-UFV; 2013 [citado 18 dez. 2019]. Disponível em: http://www.ensaiosclinicos.gov. br/rg/RBR-5n4y2g.

14. World Health Organization. Obesity: preventing and managing the global epidemic. Report of a World Health Organization Consultation. Geneva: WHO; 2000.

15. Lipschitz DA. Screening for nutritional status in the elderly. Prim Care. 1994;21(1):55-67.

16. Associação Brasileira para Estudos da Obesidade. I Diretriz Brasileira de Diagnóstico e Tratamento da Síndrome Metabólica. Arq Bras Cardiol. 2005;84(suppl 1):1-28.

17. US Department of Agriculture, Agricultural Research Service 2015. USDA National Nutrient Database for Standard Reference, Release 
28. [citado 18 dez. 2019]. Disponível em: http://ndb.nal.usda.gov/ndb/ search/list.

18. Carraro JC, Hermsdorff HH, Mansego ML, Zulet MÁ, Milagro FI, Bressan $\mathrm{J}$, et al. Higher fruit intake is related to TNF- $\alpha$ hypomethylation and better glucose tolerance in healthy subjects. J Nutrigenet Nutrigenomics. 2016;9(2-4):95-105.

19. Hermsdorff HH, Mansego ML, Campión J, Milagro FI, Zulet MA, Martínez JA. TNF-alpha promoter methylation in peripheral white blood cells: relationship with circulating TNF $\alpha$, truncal fat and n-6 PUFA intake in young women. Cytokine. 2013;64(1):265-71.

20. Willett WC, Stampfer M. Implications of total energy intake for epidemiologic analyses. In: Willett WC, editors. Nutritional Epidemiology. New York: Oxford University Press; 1998. p. 272.

21. Silva HA, Carraro JCC, Bressan J, Hermsdorff HHM. Relation between uric acid and metabolic syndrome in subjects with cardiometabolic risk. Einstein. 2015;13(2):202-8.

22. Alonso AL, Munguía-Miranda C, Ramos-Ponce D, Hernandez-Saavedra D, Kumate J, Cruz M. Waist perimeter cutoff points and prediction of metabolic syndrome risk. A study in a Mexican population. Arch Med Res. 2008;39(3):346-51.

23. Alberti KG, Eckel RH, Grundy SM, Zimmet PZ, Cleeman JI, Donato KA, et al. Harmonizing the metabolic syndrome: a joint interim statement of the International Diabetes Federation Task Force on Epidemiology and Prevention; National Heart, Lung, and Blood Institute; American Heart Association; World Heart Federation; International Atherosclerosis Society; and International Association for the Study of Obesity. Circulation. 2009;120(16):1640-5.

24. Ashwell M, Hsieh SD. Six reasons why the waist-to-height ratio is a rapid and effective global indicator for health risks of obesity and how its use could simplify the international public health message on obesity. Int J Food Sci Nutr. 2005;56(5):303-7.

25. World Health Organization. Obesity: preventing and managing the global epidemic. Geneva: WHO; 1998.

26. Vasques AC, Rosado LE, Rosado GP, Ribeiro RC, Franceschini SCC, Geloneze B, et al. Predictive ability of anthropometric and body composition indicators in the identification of insulin resistance. Arq Bras Endocrinol Metabol. 2009;53(1):72-9.

27. Bray GA, Bouchard C, James WPT. Definitions and proposed current classifications of obesity. Handbook of obesity. New York: Marcel Dekker; 1998.

28. Mohammadabadi F, Vafaiyan Z, Hosseini SM, Aryaie M, Eshghinia S. Assessment of insulin resistance with two methods: HOMA-IR and TyG index in Iranian obese women. IJDO. 2014;6(1):23-7.

29. Willett W, Stampfer M. Implications of total energy intake for epidemiologic analyses. In: Willett W. Nutritionalepidemiology. 2nd ed. New York: Oxford University Press; 1998.

30. Brandão JM, Fernandes CS, Barroso SG, Rocha GS. Association of fiber intake and cardiovascular risk in elderly patients. Int J Cardiovasc Sci. 2015;28(6):464-71.

31. Henson S, Blandon J, Cranfield J, Herath, D. Understanding the propensity of consumers to comply with dietary guidelines directed at heart health. Appetite. 2010;54(1):52-61

32. Ribak PA, Ghisleni CP, Zemolin GP, Zanardo VPS. Nutritional status, fatty acid consumption and its relationship with lipid profile patient. Perspectiva. 2016;40(149):85-95.

33. Zelman, K. The great fat debate: a closer look at the controversy questioning the validity of age-old dietary guidance. J Am Diet Assoc. 2011;111(5):655-8.

34. Ooi EM, Watts GF, Ng TW, Barrett PH. Effect of dietary fatty acids on human lipoprotein metabolism: a comprehensive update. Nutrients. 2015;7(6):4416-25.
35. Micha R, Mozaffarian D. Saturated fat and cardiometabolic risk factors, coronary heart disease, stroke, and diabetes: a fresh look at the evidence. Lipids. 2010,45(10):893-905.

36. Courchesne-Loyer A, Fortier M, Tremblay-Mercier J, Chouinard-Watkins R, Roy M, Nugent S, et al. Stimulation of mild, sustained ketonemia by medium-chain triacylglycerols in healthy humans: Estimated potential contribution to brain energy metabolism. Nutrition. 2013;29(4):635-40.

37. Colleone VV. Aplicações clínicas dos ácidos graxos de cadeia média. In: Curi R, Pompéia C, Miyasaka CK, Procopio J, editores. Entendendo a gordura: os ácidos graxos. São Paulo: Manole; 2002. p. 439-54.

38. Assunção ML, Ferreira HS, dos Santos AF, Cabral CR Jr, Florêncio TM. Effects of dietary coconut oil on the biochemical and anthropometric profiles of women presenting abdominal obesity. Lipids. 2009;44(7):593-601.

39. St-Onge MP, Ross R, Parsons WD, Jones PJ. Medium-chain triglycerides increase energy expenditure and decrease adiposity in overweight men. Obes Res. 2003;11(3):395-402

40. Tsuji H, Kasai M, Takeuchi H, Nakamura M, Okazaki M, Kondo K. Dietary medium-chain triacylglycerols suppress accumulation of body fat in a double-blind, controlled trial in healthy men and women. J Nutr. 2001;131(11):2853-9.

41. Ehlers K, Brand T, Bangert A, Hauner H, Laumen H. Postprandia activation of metabolic and inflammatory signalling pathways in human peripheral mononuclear cells. Br J Nutr. 2014;111(12):2167-75.

42. Emerson SR, Kurti SP, Harms CA, Haub MD, Melgarejo T, Logan C, et al. Magnitude and timing of the postprandial inflammatory response to a high-fat meal in healthy adults: a systematic review. Adv Nutr. 2017;8(2):213-25.

43. Rocha DM, Caldas AP, Oliveira LL, Bressan J, Hermsdorff $\mathrm{HH}$. Saturated fatty acids trigger TLR4-mediated inflammatory response. Atherosclerosis. 2016;244(1):211-5

44. Mani V, Hollis JH, Gabler NK. Dietary oil composition differentially modulates intestinal endotoxin transport and postprandial endotoxemia. Nutr Metab. 2013;10(1):6.

45. Moreira AP, Texeira TF, Ferreira AB, Peluzio MC, Alfenas RC. Influence of a high-fat diet on gut microbiota, intestinal permeability and metabolic endotoxaemia. Br J Nutr. 2012;108(5):801-9.

46. Ridker PM, Buring JE, Cook NR, Rifai N. C-reactive protein, the metabolic syndrome and risk of incident cardiovascular events: an 8-year follow-up of 14,719 initially healthy American women. Circulation. 2003;107(3):391-7.

47. Brown DW, Giles WH, Croft JB. White blood cell count: an independent predictor of coronary heart disease mortality among national cohort. J Clin Epidemiol. 2001;54(3):316-22.

48. Raz O, Steinvil A, Berliner S, Rosenzweig T, Justo D, Shapira I. The effect of two iso-caloric meals containing equal amounts of fats with a different fat composition on the inflammatory and metabolic markers in apparently healthy volunteers. J Inflamm. 2013;10(1):3.

49. Klein-Platat C, Drai J, Oujaa M, Schlienger JL, Simon C. Plasma fatty acid composition is associated with the metabolic syndrome and low-grade inflammation in overweight adolescents. Am J Clin Nutr. $2005 ; 82(6): 1178-84$

50. Kunesova M, Hainer V, Tvrzicka E, Phinney SD, Stich V, Parízková J, et al. Assessment of dietary and genetic factors influencing serum and adipose fatty acid composition in obese female identical twins. Lipids. 2002;37(1):27-32

51. Paillard F, Catheline D, Duff FL, Bouriel M, Deugnier Y, Pouchard M, e al. Plasma palmitoleic acid, a product of stearoyl-coA desaturase activity, is an independent marker of triglyceridemia and abdominal adiposity. Nutr Metab Cardiovasc Dis. 2008;18(6):436-40.

52. Mahendran Y, Agren J, Uusitupa M, Cederberg H, Vangipurapu J, Stančáková A, et al. Association of erythrocyte membrane fatty acids 
with changes in glycemia and risk of type 2 diabetes. Am J Clin Nutr. 2014;99(1):79-85.

53. Zong G, Ye X, Sun L, Li H, Yu Z, Hu FB, et al. Associations of erythrocyte palmitoleic acid with adipokines, inflammatory markers, and the metabolic syndrome in middle-aged and older Chinese. Am J Clin Nutr. 2012;96(5):970-6.

54. Petersson H, Lind L, Hulthe J, Elmgren A, Cederholm T, Risérus U. Relationships between serum fatty acid composition and multiple markers of inflammation and endothelial function in an elderly population. Atherosclerosis. 2009;203(1):298-303.

55. Zong G, Zhu J, Sun L, Ye X, Lu L, Jin Q, et al. Associations of erythrocyte fatty acids in the de novo lipogenesis pathway with risk of metabolic syndrome in a cohort study of middle-aged and older Chinese. Am J Clin Nutr. 2013;98(2):319-26.

56. Kröger J, Zietemann V, Enzenbach C, Weikert C, Jansen EH, Döring F,et al. Erythrocyte membrane phospholipid fatty acids, desaturase activity, and dietary fatty acids in relation to risk of type 2 diabetes in the European Prospective Investigation into Cancer and Nutrition (EPIC)-Potsdam Study. Am J Clin Nutr. 2011;93(1):127-42.

57. Djoussé L, Matthan NR, Lichtenstein AH, Gaziano JM. Red blood cell membrane concentration of cis-palmitoleic and cis-vaccenic acids and risk of coronary heart disease. Am J Cardiol. 2012;110(4):539-44.

58. Djoussé L, Weir NL, Hanson NQ, Tsai MY, Gaziano JM. Plasma phospholipid concentration of cis palmitoleic acid and risk of heart failure. Circ Heart Fail. 2012;5(6):703-9.

59. Volk BM, Kunces LJ, Freidenreich DJ, Kupchak BR, Saenz C, Artistizabal JC, et al. Effects of step-wise increases in dietary carbohydrate on circulating saturated fatty acids and palmitoleic acid in adults with metabolic syndrome. PLoS One. 2014;9(11):e113605.

60. Fisberg RM, Marchioni DML, Colucci ACA. Assessment of food consumption and nutrient intake in clinical practice. Arq Bras Endocrinol Metab. 2009;53(5):617-24. 